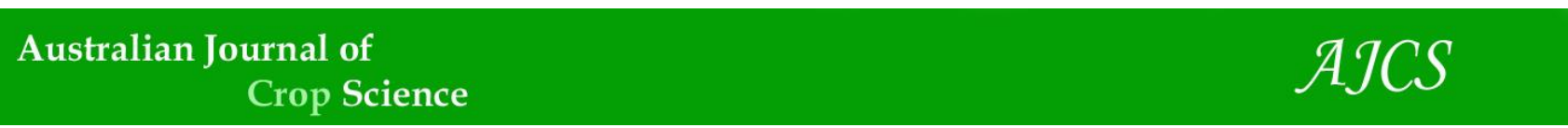

AJCS 15(01):16-22 (2021)

ISSN:1835-2707

doi: 10.21475/ajcs.21.15.01.2238

\title{
Sowing speed can affect distribution and yield of soybean
}

\author{
Luan Felipe Bortoli, Guilherme de Almeida Arismendi, Matheus Martins Ferreira, Thomas Newton \\ Martin*
}

Universidade Federal de Santa Maria, Santa Maria - RS, Brazil

*Corresponding author: martin.ufsm@gmail.com

\begin{abstract}
The sowing speed or planting speed is referred to tractor and seeder displacement speed during the sowing. It plays a crucial role intruding distribution of plants, and consecuently yield of soybean grain. Therefore, this paper endeavors to corroborate the repercussions of the sowing speeds on the plants distribuition and grain yield. The experimental design consisted of a randomized complete block design with five treatments and four replications, with the treatments comprising of five sowing speeds (2.0, 3.1, 6.1, 7.4, $9.0 \mathrm{~km} \mathrm{~h}^{-1}$ ). The following parameters were evaluated:(i) distance between plants, (ii) double spacing, acceptable spacing and failing spacing, (iii) number and dry mass of nodules, (iv) plant population, (v) shoot dry mass, (vi) mass of one thousand grains, and (vii) grain yield. With the increase in the sowing speed, the equidistance of plants in the row was changed, which in turn decreased the soybean yield. The results showed that seeding speeds close to $4.0 \mathrm{~km} \mathrm{~h}^{-1}$ provided better uniformity and distribution of plants in the row. The results also unveiled that sowing speed mainly influence the plants distribution, having greater influence on the productivity components, thereby affecting the overall soybean grain yield.
\end{abstract}

Keywords: distance between plants; failing spacing; intraspecific competition; Glycine max L.; planting uniformity. Abbreviations: DP_distance between plants; FS_failing spacing; AS_acceptable spacing; DS_double spacing; PP_plant population; NN_number of nodules; MSN_nodules dry mass; MSPA_shoot dry mass; MMG_mass of 1000 grains; PG_grain yield; FV_font of

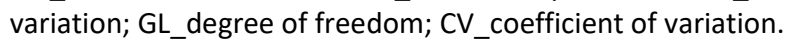

\section{Introduction}

In the past several years, the soybean [Glycine max (L.) Merr.] has gained tremendous attention because it is one of the most economically important oil plants in Brazil. This growing attention has accelerated the cultivation of the crop in the country, with the increment in the area by 1.2 million hectares for cultivation, followed by a subsequent rise in the production up to 118.048 thousand tons in the $2017 / 2018$ harvest (Conab, 2018). The annual increase in production can be attributed to the improvement of cultivation technologies, along with the launch of more productive cultivars, allied mainly to the growth of the area. However, the average yield of the crop does not move hand-in-hand with the trend of the production. Indeed, it has remained stable in the last years even with the improvement of the cultivars that provides an average genetic gain of $43 \mathrm{~kg} \mathrm{ha}^{-1}$ year $^{-1}$ (De Felipe et al., 2016). Contrastingly, in the crops that are allied with the use of the high level of technologies, the attainment of highest soybean yields have been witnessed (Schuch and Peske, 2012). These higher yields can be achieved, by using more precise and well-regulated tools at the time of sowing.

With a great emphasis on the sowing technologies, the mode of sowing has been affirmed to be one of the vital factors that mostly intervene in the population and establishment of the plants in the area. Apart from this, the density of plants is a component that can adjust the soybean yield to some limits, (Petter et al., 2016; Masino et al., 2018). Typically, lower sowing density is compensated via increased pod production demonstrated by the increase in the number of branches (Manuad et al., 2010) and the photosynthetic capacity of the crop (Petter et al., 2016). A lower plant density is possibly insufficient to achieve high productivity, even though there is greater availability of environmental resources (such as light, water, and nutrition) than the need of the plants for its compensatory capacity. A low population of plants produces fewer pods per area, and consequently lower productivity (Ludwig et al., 2011; Cruz et al., 2016). Contrastingly, population and density of plants more than resources also leads to reduction in the productivity (Petter et al., 2016), because it leads to several other issues such as problems related to lodging (Balbinot Junior, 2011) and more severe diseases such as Asian rust (Lima et al., 2012). Thus, all the above points highlight that at the time of sowing seed, the adequate distribution of plants is indispensable.

To achieve effecient sowing operation in a specific agroclimatic zoning of the crop, we will show that the sowing area and the operational capacity must increase parallelly. In other words, with an increase in the sowing area, the operational capacity must be increased. Moreover, this can be achieved, by sowing seeds at higher speeds, i.e. sowing a larger area in a shorter time. However, the increased sowing velocity is accompanied by additional operating costs, apart from influencing the seed deposition in the sowing groove as well as altering the spacing between plants (Bertelli et al., 2016). Further, to rule out the 
intraspecific competition leading to the loss of crop productivity, one of the most fundamental factors that need to be controlled is the distribution of the plants in the sowing row, which can vary according to the sowing techniques (Heiffig et al., 2006; Jasper et al., 2011). Therefore, employing the most accurate seed distribution systems along with the more adequate displacement speeds may possibly result in more equidistant seed distribution in the sowing furrow (Karayel, 2009; Bertelli et al., 2016). However, there is no unique and definite velocity that can drive the uniform distribution of the plants in the row. There is also no information on the impact of distribution on yield of soybean grains. Concerning the sowing process, Pacheco et al. (1996) mentioned that seeds released by the sowing machine mechanisms acquire two components of the velocity (i) vertical, due to the free fall of the seed, and (ii) horizontal, due to the displacement of the machine. Among the two components, the horizontal velocity component directs the seed to exhibit impact on the soil by jumping out of the target site, which in turn alters the spacing between the seeds. Thus, the compensatory capacity possessed by the soybean plant, may or may not allow alterations in the components of the soybean yield, to the extent up to which plant population and the homogeneity of plant distribution undergoes changes (Cunha, 2018). Upon taking into account the plant density, few studies have demonstrated that soybean plants show a moderate response to the variations in the plant density (Heiffig et al., 2006; Procópio et al., 2013). On a similar note, Procópio et al. (2013) have affirmed that the soybean possesses high phenotypic plasticity, which is able to modulate its growth and the components of productivity as a function of the arrangement of plants, being able to compensate the variations in the row. However, the different environmental and management factors lead to huge variations in the situations, leading to unvalidated scientific results which quantify and discusses the agronomic response of soybean to the variations of plants within the row caused by different sowing speeds. The distribution of plants in the sowing row is still a controversial issue in Brazil due to existence of several factors such as (i) no-tillage system (Febrapdp, 2013), (ii) soil diversity (Embrapa, 2013), (iii) different seed metering mechanisms (Machado, Reynaldo, 2017), and (iv) the necessity to adapt to the indicated zoning for the culture exist. This ensures the presence of divergence on the subject. Thus, the current work intends to corroborate the impact of different sowing speeds on the distribution of plants in the row together with its influence on the yield of soybean grains.

\section{Results and Discussion}

\section{First season}

The analysis revealed that, in the first year, the seed speed had a significant impact on various parameters such as (i) plant spacing, (ii) acceptable spacings, (iii) double spacings, (iv) nodule numbers, (v) nodule dry mass, and (vi) soybean grain yield. However, (1) plant population, (2) shoot dry mass, and (3) the mass of a thousand grains remain unaltered. Interestingly, in the second year, the variation in speed led to significant alterations in (a) plant spacings, (b) double spacings, (c) plant population, (d) nodule dry mass, (e) shoot dry mass, and (f) grain yield, with no changes in (i) the number of nodules, and (ii) the mass of a thousand grains (Table 1).

In the 2016/2017 crop season, the sowing speed of $3.9 \mathrm{~km} \mathrm{~h}$ 1 resulted in the largest distance between soybean plants $(9.5 \mathrm{~cm}$ ) (Figure 1a). Contrastingly, in the 2017/2018 crop, the speed of $2.0 \mathrm{~km} \mathrm{~h}^{-1}$ (see Figure $1 \mathrm{~b}$ ) led to the largest distance $(22.1 \mathrm{~cm})$ between plants. Predominantly, in the second year, the distances obtained at all speeds were above the expected spacing of $7.0 \mathrm{~cm}$, probably due to the employed seed metering system. However, the $4.3 \mathrm{~km} \mathrm{~h}^{-1}$ speed obtained a distance of $9.5 \mathrm{~cm}$ between plants, the value being the nearest to the expected spacing. Overall, in both the years, the outcome of all the sowing speeds close to $4.0 \mathrm{~km} \mathrm{~h}^{-1}$, was a distance of $9.5 \mathrm{~cm}$ between plants, revealing that at these speeds only small variations were observed in plant spacings.

Taking into consideration the double spacings between the plants, the lowest and highest percentage of DS i.e. $0.86 \%$ and $27.6 \%$, in the first year, was observed at a speed of 3.7 $\mathrm{km} \mathrm{h}^{-1}$ and $7.6 \mathrm{~km} \mathrm{~h}^{-1}$, respectively (Figure $1 \mathrm{c}$ ).

\section{Second season}

Alternatively, in the second year, the double spacings between plants increased linearly with an increase in the sowing speed (Figure $1 \mathrm{~d}$ ). On the other hand, the sowing speed altered the acceptable spacings (AS) only in the first year, with AS decreasing by $26 \%$ upon increasing the speed from $2 \mathrm{~km} \mathrm{~h}^{-1}$ to $9 \mathrm{~km} \mathrm{~h}^{-1}$ (Figure $1 \mathrm{e}$ ). In the first year, the speed of $3.1 \mathrm{~km} \mathrm{~h}^{-1}$, rendered a greater number of nodules (NN) as well as a higher dry mass of nodules (MSN) (Figure $1 \mathrm{f}$ and g). On the contrary, in the second year, with the increase of sowing speed, a linear reduction in the dry mass of nodules was observed (Figure 1h). Possibly, the observation of higher values of NN and MSN, at the lower speeds, can be expounded on the basis of the presence of a smaller number of double spacings at lower speeds. However, with larger plant spacing, the photosynthetic rate per plant also increased (Petter et al., 2016), which in turn, increases the carbon supply to the nodules, causing an increase in the nodulation (Hungria, 2014).

\section{Discussion}

The analysis also showed that with increasing sowing speed, the uniformity of the plants in the row will decrease. On a similar way in the present work, a reduction in the number of failures and doubles was observed with an increase in sowing speed (Cortez et al., 2006; Bertelli et al., 2016). Therefore, we conclude that before the commencement of the sowing process, the selection of the appropriate speed is very crucial because a uniform distribution of plants within the sowing row can cause a loss in the crop productivity (Tourino et al., 2002).

Pacheco et al. (1996) further explained the occurrence of unevenness of plants in the row, with increasing sowing speed. They described the process of sowing seed, during which, they observed that the seeds have their initial point of contact ever closer to the upper end of the metering tube. Furthermore, with an increase in the angle of contact, the number of impacts of the seed inside the tube was increased remarkably. Additionally, the process of arranging the seeds on the horizontal disc (used for sowing seed), requires an adequate amount of time for filling all the alveoli of the disk. Moreover, even if the entrance of the alveolus is lower or 
decreased, double spacing can occur, because a seed has a tendency to stay in the socket as well as in the access ramp to the socket. Further comparisons between first and second year showed a uniform distribution of plants in the row in the second year than in the first year. This observation, perceived by means of the lower percentage of double spacings (Figure 1d) and the non-significance values for acceptable and faulty spacings as a function of sowing speed in the second year (Table 1). This may be related to the seed dosing mechanism that considered being more accurate. Indeed, the system utilized is characterized mainly by the presence of two extra seed organizers, making the seed to reach into each row in a suitably organized in the seed dispenser system. Accordingly, for the less precise seed distribution mechanisms, Dias et al. (2009) mentioned that lower velocities are favored since it leads to less uniformity. Similarly, in the case of more precise mechanisms such as those of pneumatic seeders, Bertelli et al. (2016) and Carpes et al. (2017) have affirmed that increasing seeding speed causes a reduction in acceptable spacings. Thus, we can deduce that irrespective of the system used for seeding, speed makes a major contribution in the distribution of plants, thereby leading to uniformity in each row.

In order to have a more clear vision regarding the effect of sowing speeds, Brandelero et al. (2015), carried out the sowing of seeds at higher speed and noticed that higher speeds cause greater movement of the soil in the sowing groove, which in turn promotes greater incorporation of the straw. Moreover, the removal of this straw further raises the temperature of the soil (Rodrigues et al., 2018). As a result, the moisture content of the sowing row gets reduced (Ribeiro et al., 2016). In other words, the soil becomes more susceptible to higher temperatures, which gives rise to water deficiencies and further drives the bacteria in the soil to adopt the symbiotic mechanism. In fact, the reduction in the number of nodules and dry matter of these nodules validate the adoption of the symbiotic process as the seeding rate increases.

Upon taking into account the plant population and the dry mass of the aerial part of the soybean, we observed that sowing speed exerts its effect on both the parameters only in second year. Evidently, a velocity of $4.2 \mathrm{~km} \mathrm{~h}^{-1}$ leads to the largest plant population, whereas the speed of $7.7 \mathrm{~km} \mathrm{~h}^{-1}$ gives rise to highest dry mass (see Figure $2 a$ and b). Explicitly, the plant population at a speed of $7.7 \mathrm{~km} \mathrm{~h}^{-1}$ was lower than $4.2 \mathrm{~km} \mathrm{~h}^{-1}$, corroborating that higher velocities cause alterations in one of the main productivity components.

Similarly, at higher speeds, grain productivity also is reduced in the first and second year (see Figure $2 c$ and $d$ ). Additionally, productivity reached the lowest value at $7.8 \mathrm{~km}$ $\mathrm{h}^{-1}$ and $9.0 \mathrm{~km} \mathrm{~h}^{-1}$, in the first and second year, respectively, with the reduction being $1,556 \mathrm{~kg} \mathrm{ha}^{-1}$ (first year) upon increasing the speed from 2.0 to $7.8 \mathrm{~km} \mathrm{~h}^{-1}$, and 1,037 $\mathrm{kg} \mathrm{ha}^{-}$ ${ }^{1}$ (second year) with an increase in the speed from 5.1 for 9.0 $\mathrm{km} \mathrm{h}^{-1}$. However, the application of the regression equation for the first year establishes the highest productivity of grains with the speed of $2 \mathrm{~km} \mathrm{~h}^{-1}$. But, upon extending the concept of significant minimum difference to Tukey (DMS), followed by further estimation, the reduction in grain productivity is found to be $485.52 \mathrm{~kg} \mathrm{ha}^{-1}$, instead of 5101.57 $\mathrm{kg} \mathrm{ha}^{-1}$, with the limiting speed that reduces DMS, being 3.0 $\mathrm{km} \mathrm{h}^{-1}$. Likewise, considering the maximum point $15.09 \mathrm{~km}$ $\mathrm{ha}^{-1}$ ) of the regression equation for the second year (DMS $489.36 \mathrm{~kg})$, the sowing speed falls in the range of 2.5 to 7,7 $\mathrm{km} \mathrm{h}^{-1}$, without causing significant loss of grain yield. Thus, the two years of our experiment confirmed that the theoretical limits that maximize grain yield vary between 2.5 and $3.0 \mathrm{~km} \mathrm{ha}^{-1}$.

Since the plant population was observed to be less at higher seed sowing speeds (Figure $2 b$ ), the shoot dry mass per plant at these speeds was found to be higher (Figure 2a), promoting accretion in the growth rate of individual plant (Masino et al., 2018). Notably, the highest dry mass of the aerial part is vital, as it is directly associated with the filling of the grains (Procopio et al., 2013), in which the productivity was lower in the velocities that presented higher shoot dry mass per plant. Possibly, we could elucidate this observation owing to the presence of a lower number of plants, which produces the lower dry mass of leaves, branches (Procopio et al., 2013) and pods by area (Cruz et al., 2016). In the same context, Modolo et al. (2012) have corroborated that upon varying the sowing speed form 3.0 to $6.8 \mathrm{~km} \mathrm{~h}^{-1}$, the productivity of the soybean grains reduced by $505.75 \mathrm{~kg} \mathrm{ha}^{-1}$. Moreover, the authors related this reduction of productivity to the smallest plant stand due to an increase in the speed, with reduction from 13.8 to 12.9 $\mathrm{m}^{-1}$ plants. On the contrary, when there is no change in plant population with increased sowing speed, soybean grain yield is not affected (Jasper et al., 2011). Modolo et al. (2012), related the reduction in the soybean yield to the lower plant population in the area as a result of higher speed. Nevertheless, the plant population, as one of the components of productivity, is influenced by the increasing sowing speed to a less extent; even it increases faults and doubles. The density of plants is maintained, because the change in the number of acceptable spacings is compensated by the increase of the double spacings (Dias et al., 2009; Bertelli et al., 2016). Overall, in the two years of the experiment, higher sowing speeds led to an elevation in the deworming of plants but diminution in the grain yield. Nonetheless, the factor that defines the final crop yield like plant population was found to undergo reduction only in the second year of the experiment (Masino et al., 2018). This, in turn, draws attention towards the importance of the ability to compensate for the lack of very close plants in grain yield. Apart from plant population, other parameters such as the ability of the cultivar to maintain a larger number of pods and consequently grain production should also be highlighted and evaluated. In the same context, Stivers; Swearingin (1980) illustrated that soybean's ability to compensate for variations within the row is also related to the relative maturation group of the cultivar, and soybean cultivars with a longer cycle have a greater compensatory capacity. Most likely, these cultivars present a higher vegetative period and leaf area index (LAI) (Santachiara et al., 2017). However, the sowing date should also be taken into consideration, since it is directly related to the maximum LAl of each maturation group (Tagliapietra et al., 2017).

\section{Materials and Methods}

In the current investigation, the experiment was conducted in two years in the experimental area of the Department of Plant Science of the Federal University of Santa Maria, with the geographical co-ordinates of 2942' south latitude, 5342' west longitude, and 116 meters altitude. Furthermore, the soil of the area was classified, as Argisol dystrophic arenico Red (Embrapa, 2013), which corresponds 
Table 1. Summary of variance analysis to authenticate the effect of sowing speed, with the respective average squares of the variables such as distance between plants (DP), failing spacing (FS), acceptable spacing (AS), double spacing (DS), plant population (PP), number of nodules plant ${ }^{-1}$ (NN), nodules dry mass (MSN), shoot dry mass (MSPA), mass of 1000 grains (MMG) and soybean grain yield (PG) in the year 2016/2017 and 2017/2018.

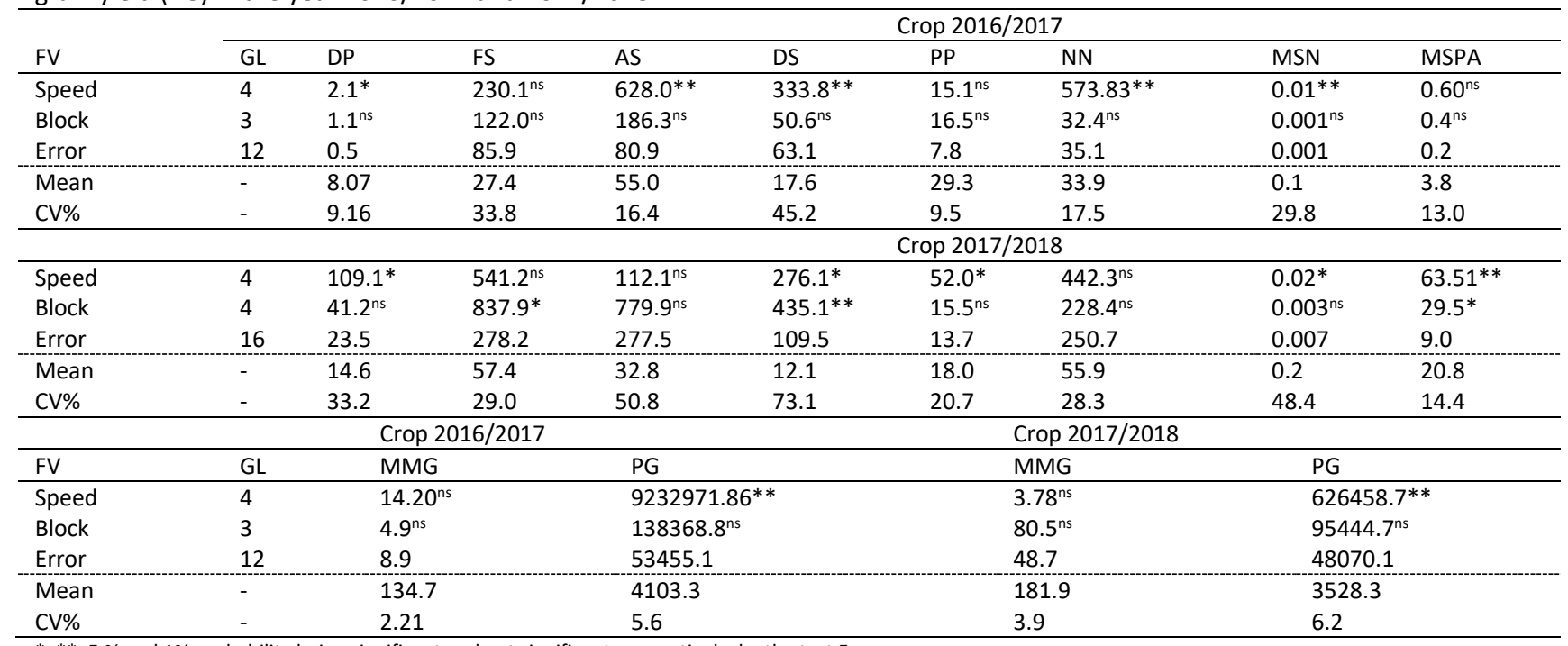

$*^{*}, * *, 5 \%$ and $1 \%$ probability being significant and not significant, respectively, by the test $\mathrm{F}$.
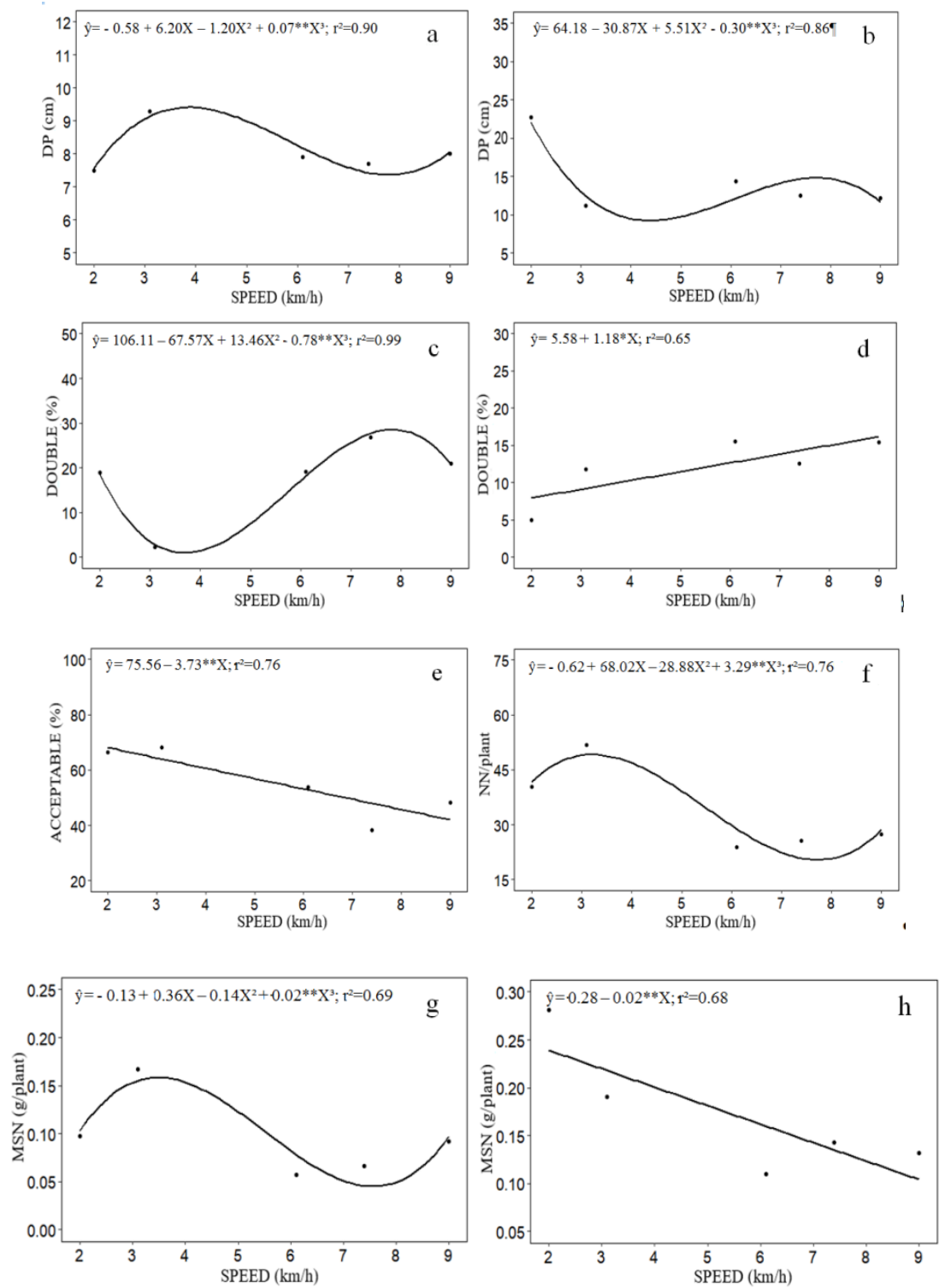

Figure 1. Distance between plants (DP), double and acceptable spacings, the number of nodules (NN), and dry mass of soybean nodules (MSN) as a function of sowing speed, in Santa Maria-RS, harvest 2016/17 (a, c, e, f, and g) and harvest 2017/18 (b, d, and h). 

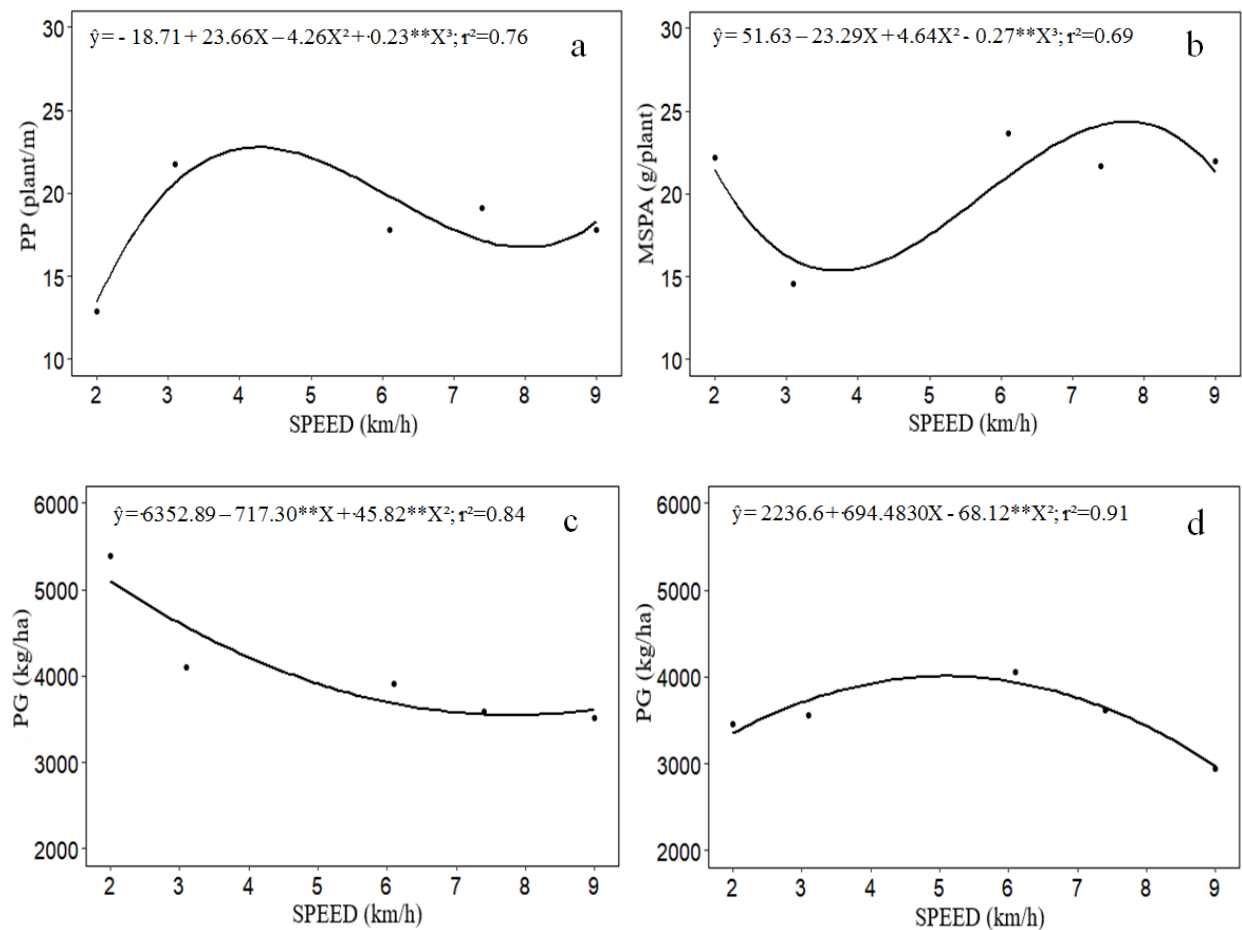

Figure 2. The plant population (PP), shoot dry mass (MSPA), and grain yield (PG) of soybean as a function of sowing speed. Santa Maria-RS, harvest 2016/17 (c) and 2017/18 (a, b, and d).

corresponding to the Ultisol according to the classification of Soil Taxonomy (Soil Survey Staff, 2014). Additionally, the climate of the region is subtropical with temperate rainy weather, which is further termed as Cfa type climate, according to the Köppen climate classification (Peel et al., 2007).

The experimental design consisted of a randomized block design with five treatments and four replications. Primarily, a plot of an area of $17.4 \mathrm{~m}^{2}$ was selected for the experiment and was subjected to the treatments, which mainly includes five sowing speeds, i.e. 2.0, 3.1, 6.1, 7.4, $9.0 \mathrm{~km} \mathrm{~h}^{-1}$.

\section{Planting material}

Furthermore, the soybean cultivar, Brasmax Ponta IPRO 7166 were utilized for the study. The seeds of this cultivar were sown in five rows using Sfil ${ }^{\circledR}$ fertilizer sowing machine, with the sower being regulated for maintaining a row spacing of $0.45 \mathrm{~m}$ and a density of 15 seed $\mathrm{m}^{-1}$. In the first year, the sowing of seeds was done on November 16, 2016, using the alveolate horizontal disk seed dosing mechanism, whereas seeds; while in the second year, seeds were sown on November 28, 2017, using J. Assy APOLLO AGRíCOLA's Titanium $^{\circledast}$ system. The tractor used to pull the seeder was a Massey Fergunson with 55.16 kW of power.

\section{Variables measured}

During the experiment, the variables evaluated are as follows, (i) the distance between plants (DP), (ii) failing spacing (FS), acceptable spacing (AS) and double spacing (DS), (iii) plant population (PP), (iv) number of nodules (NN), (v) nodules dry mass (MSN), (vi) shoot dry mass (MSPA), (vii) mass of 1000 grains (MMG), and (viii) grain yield (PG).

In the V6 stage, the distance between the plants (DP) was measured within three meters in each row of sowing using a metric scale, with (a) FS being considered, as the spacings above 1.5 times the expected spacing, (b) AS being defined, as the spacings between plants greater than 0.5 times but smaller than 1.5 times the spacing $(7 \mathrm{~cm})$, and (c) DS being the spacings smaller than 0.5 times the expected spacing. On the other hand, the estimation of plant population (PP) was carried out by counting the plants within three meters in each row of sowing. Furthermore, for evaluating the number of nodules (NN), the plants were collected in a linear meter in each plot using a cutter blade, followed by the counting of the nodes present on each plant. In order to determine MSN and MSPA, the plants were oven dried at 65 으 for 72 hours and were subsequently weighed in an analytical balance with the measurement being accurate up to four decimal places. At the time of harvest, the mass of one thousand grains (MMG) and grain yield (PG) was evaluated, by collecting $6.75 \mathrm{~m}^{2}$ from each row, followed by weighing the grains of any useful area of the plot. Moreover, to obtain accurate values of MMG and PG, the obtained experimental values of MMG and PG were corrected to standard moisture of $13 \%$ (Brasil, 2009).

\section{Statistical analysis}

Eventually, the data were subjected to analysis of variance at $5 \%$ error probability. Upon validating the significant effect, from the results of analysis of variance, the regression analysis was performed using Sisvar software (Ferreira, 2011).

\section{Conclusion}

The higher velocities favored the unevenness of plants due to the increase in the number of double spacings and reduction in the number of acceptable spacings. Additionally, the yield of the soybean bean grain was reduced even though there was no change in the plant population in the area in the first year, which implies that 
most likely the plant variations in the row remain uncompensated by the soybean crop. The increase in the unevenness of plants in the row caused by the increase of the speed of sowing decreased soybean grain yield, with the seeding speeds close to $4.0 \mathrm{~km} \mathrm{~h}^{-1}$ providing better uniformity and distribution of plants in the row.

\section{Acknowledgments}

Thanks to the National Council for Technological Development (CNPq), the Coordination for the Improvement of Personal Higher Education (CAPES) and the Foundation for Support to Research of the State of RS (FAPERGS) for the financial support of the research.

\section{References}

Bertelli GA, Jadoski SO, Da Luz Dolato M, Rampim L, Maggi MF (2016) Plantability performance of pneumatic seeders in the soybean culture implantation in the Piaui cerradoBrasil. Appl Res Agrotec. 9 (1): 91-103.

Balbinot JAA (2011) Acamamento de plantas na cultura da soja. Revista Agrop Catarinense. 25 (1): 40-43.

Brandelero EM, Adami PF, Modolo AJ, Baesso MM, Fabian AJ (2015) Seeder performance under different speeds and its relation to soybean cultivars yield. J Agron Crop Sci. 14 (3): 139-145.

Brasil. Ministério da Agricultura (2009) Pecuária e Abastecimento. Regras para análise de sementes. Brasília: Secretaria de Defesa Agropecuária. 399.

Carpes DP, Alonço ADS, Rossato FP, Veit AA, Souza LBD, Francetto TR (2017) Effect of different conductor tubes on the longitudinal distribution of corn seeds. RBEAA. 21 (9): 657-662.

Cruz SCS, Junior DGS, Dos Santos DMA, Lunezzo LO, Machado CG (2016) Cultivo de soja sob diferentes densidades de semeadura e arranjos espaciais. Rev. Agric. Neotrop. 3 (1): 1-6.

Companhia Nacional De Abastecimento (2017) Acompanhamento as safra brasileira de grãos. Brasília: Conab, 5 (1): 144.

Cortez JW, Furlani CE, Silva RPD, Lopes A (2006) Distribuição longitudinal de sementes de soja e características físicas do solo no plantio direto. Eng Agríc. 26 (2): 502-510.

Cunha VSDos (2018) Distribuição espacial e redução do estande inicial de plantas na cultura da soja. Tese (Doutorado em Programa de Pós-Graduação em Agronomia) - Universidade Federal de Santa Maria. 96 (1).

De Felipe M, Gerde JA, Rotundo JL (2016) Soybean genetic gain in maturity groups III to $\mathrm{V}$ in Argentina from 1980 to 2015. Crop Science. 56 (6): 3066-3077.

Dias OV, Alonço AS, Baumhardt UB, Bonotto JG (2009) Distribuição de sementes de milho e soja em função da velocidade e densidade de semeadura. Cien Rural. 39 (6) 1721-1728.

Empresa Brasileira de Pesquisa Agropecuária (2013) Sistema brasileiro de classificação de solos. Rio de Janeiro: Ministério da Agricultura e do Abastecimento. 353.

Federação Brasileira de Plantio Direto na Palha (2013) O que é sistema plantio direto? Avaible in :<https://febrapdp.org.br/sistema-plantio-direto-o-que-e>. Access in 11 October. 2018.

Ferreira DF (2011) Sisvar: a computer statistical analysis system. Cien e Agrotec. 35 (6):1039-1042.
Hungría M, Luca MJ de (2014) Densidade das plantas e modulação da fixação de nitrogênio simbiótica na soja. Sci Agric. 71 (3): 181-187.

Heiffig LS, Câmara GMS, Marques LA, Pedroso DB, Piedade SMS (2006) Fechamento e índice de área foliar da cultura da soja em diferentes arranjos espaciais. Brag. 65 (2): 285-295.

Jasper R, Assumpção OSM, Rocil J, Garcia LC (2011) Velocidade de semeadura da soja. Eng Agric. 31 (1): 102110.

Lima SFDe, Alvarez RDCF, De Faria Theodoro G, Bavaresco M, Silva KS (2012) Efeito da semeadura em linhas cruzadas sobre a produtividade de grãos e severidade da ferrugem asiática da soja. Biosci J. 28 (6): 954-962.

Karayel D (2009) Performance of a modified precision vacuum seeder for no-till sowing of maize and soybean Soil \& Tillage Research. 104 (1): 121-125.

Ludwig MP, Dutra LMC, Lucca Filho AO, Zabot L, Jaue A, Uhry D (2011) Populações de plantas na cultura da soja em cultivares convencionais e Roundup Ready. Rev Ceres. 58 (3): 305-313.

Machado TM, Reynaldo ÉF (2017) Avaliação de diferentes semeadoras e mecanismos dosadores de sementes em relação à velocidade de deslocamento. Energ Agric. 32 (1): 12-16.

Manuad M, Silva TLB, Neto AIA, Abreu VG (2010) The influence of sowing density on agronomic characteristics of soybean crop. Agrarian. 3 (9): 175-181.

Masino A, Rugeroni P, Borrás L, Rotundo JL (2018) Spatial and temporal plant-to-plant variability effects on soybean yield. Eur J Agron. 98 (1): 14-24.

Modolo AJ, Trogello E, Pagliosa ES, Dallacort R, Kolling EM, Sgarbossa M (2012) Qualidade de semeadura e produtividade da soja sob diferentes sulcadores e velocidades de operação. Semina: Ciênc Agrár. 33 (6): 3009-3016.

Pacheco EP, Mantovani EC, Martyn PJ, Oliveira AC (1996) Avaliação de uma semeadora-adubadora de precisão. Pesq Agropec Bras. 31 (3): 209-214.

Peel MC, Finlayson BL, Mcmahon TA (2007) Updated world map of the Köppen-Geiger climate classification. Hydrol Earth Syst Sci. 11 (2): 1633-1644.

Petter FA, Silva JD, Zuffo AM, Andrade FR, Pacheco LP, Almeida FD (2016) Elevada densidade de semeadura aumenta a produtividade da soja? Respostas da radiação fotossinteticamente ativa. Brag. 75 (2): 173-183.

Procópio SO, Balbinot Junior AA, Debiasi H, Franchini JC, Panison F (2013) Plantio cruzado na cultura da soja utilizando uma cultivar de hábito de crescimento indeterminado. Rev de Cienc Agrar. 56 (4): 319-325.

Ribeiro LDa Silva, De Oliveira IR, Dantas JS, Da Silva CV, Da Silva GB, De Azevedo JR (2016) Variabilidade espacial de atributos físicos de solo coeso sob sistemas de manejo convencional e de plantio direto. Pesq Agrop Bras. 51 (9): 1699-1702.

Rodrigues GA, Santos GO, Carrasqueira A, Machado ER, Assirati ET, Macri RDECV (2018) Oscilações da temperatura do solo em função de quantidades de palha e horários ao longo do dia. Rev Inter Tecnol. 15 (1): 293304.

Santachiara G, Borrás L, Rotundo JL (2017) Physiological processes leading to similar yield in contrasting soybean maturity groups. Agron J. 109 (1): 158-167. 
Schuch LOB, Peske ST (2012) Falhas e duplos na produtividade. Rev Seed News. 6 (1)

Soil Survey Staff (2014) Keys to Soil Taxonomy by Soil Survey Staff Twelfth Edition. U.S. Department of Agriculture, N.R.C.S. 362.

Stivers RK, Swearingin ML (1980) Soybean yield compensation with different populations and missing plant patterns. Agron J. 72 (1): 98-102.
Tagliapietra EL, Streck NA, Da Rocha TSM, Richter GL, Da Silva MR Cera JC, Zanon AJ (2018) Optimum leaf area index to reach soybean yield potential in subtropical environment. Agron J. 110 (3): 932-938.

Tourino MCC, De Rezende PM, Salvador N (2002) Espaçamento, densidade e uniformidade de semeadura na produtividade e características agronômicas da soja. Pesq Agrop Bras. 37(8): 1071-1077. 